\title{
The Development Model Electronic Commerce of Regional Agriculture
}

\author{
Jun Kang ${ }^{*}$, Lecai Cai, and Hongchan Li \\ Institute of Computer Application, Sichuan University of Science and Engineering, \\ Zigong 643000, Sichuan Province, P.R. China, \\ Tel.: +86-135990066775; Fax: +86-813-5505966 \\ kj_sky@126.com
}

\begin{abstract}
With the developing of the agricultural information, it is inevitable trend of the development of agricultural electronic commercial affairs. On the basis of existing study on the development application model of e-commerce, combined with the character of the agricultural information, compared with the developing model from the theory and reality, a new development model electronic commerce of regional agriculture base on the government is put up, and such key issues as problems of the security applications, payment mode, sharing mechanisms, and legal protection are analyzed, etc. The among coordination mechanism of the region is discussed on, it is significance for regulating the development of agricultural e-commerce and promoting the regional economical development.
\end{abstract}

Keywords: regional, agricultural information, agricultural e-commerce, development model.

\section{Introduction}

At present, the majority of the group focuses on higher education of the population from the Internet knowledge and use in China's, although it has distributed in agricultural industry, but overall, the proportion is very low. However, the really agricultural users are limited by objective conditions, the real demand of users have been playing a discount. In recent years, the developments of the e-commerce in agriculture have gradually become the transformation of agricultural marketization, and realize the power of the agricultural modernization.

A new development model electronic commerce of regional agriculture base on the government is advanced; it is significance for regulating the development of agricultural e-commerce and promoting the regional economical development.

\section{The Present Situation of the Development of Agricultural e-Commerce}

In recent years, the Chinese government attaches great importance to the development of e-commerce in the country, On issuing the Summaries of Middle/Long Term

\footnotetext{
${ }^{*}$ Corresponding author.
} 
Science and Technology Development Plans of China, and the Development of Information Industry Plans in the Eleventh Five-year and Long Plan in 2020 Years in The Ministry of Information Industry, "the application of e-commerce platform technology" and "the agricultural informatization technology" have been listed as the key points.

China is a large agricultural nation, agricultural informatization has started. At present, the national rural e-commerce sites have more than 2000, agriculture website have more than 10,000, a lot of vegetables and fruits, sapling, livestock, cultivation of supply and demand information and related agricultural economy, the investment information are issued by these agriculture websites, play an important role in enlivening the circulation, realizing the agricultural efficiency and increasing farmers' income. There are the influence of Chinese agricultural science and technology information network, the Chinese agricultural information network, the Chinese seed group company, the seed information center, gold dragon network etc [1] .This shows that the Chinese agricultural electronic commerce is moving into a fast development period.

But, according to statistics, the Internet users of engaging in agriculture in proportion in less than $1 \%$ in the nearly 78 million Internet users, and most of users are the agricultural management and technical personnel. And they are highly focused on the economy developed cities like Beijing, Shanghai, Guangdong, Zhejiang, Jiangsu and other regions, the real Internet farmers are almost negligible.

\section{The Factor Analysis of Restrict Regional Agricultural e-Commerce Development}

To sum up, there are some factors about restricting agricultural development of e-commerce as following [2-3]:

(1) The agricultural informatization level is low. There are lots of phenomenon in China, for example, the agricultural company informatization level is lower, the information of the network is not popular; the number of the agricultural e-commerce websites are limited, and online trading function is not complete; Internal management informatization is serious insufficient.

(2) Enterprise electronic commerce ideas are lagging. Most of our agricultural enterprises of the network to be understood, acceptant and application of ability are not high by itself; the concept of the utilizable network business are unclear, modern management ideas, method and technology of consciousness are lack, Electronic commerce constructions have large investment, long period, the large amount of maintenance.

(3) Consciousness of e-commerce is decreasing. Some enterprises in the "blind leading" process of implementing e-commerce pursue advanced hardware equipments and mature technology, and neglect integration and optimization of the enterprise internal and external information resources, and hard to obtain high quality, high efficiency and benefit of the business enterprise.

(4) e-commerce environment is imperfect. At present, China's e-commerce involved banking, information industry, taxation, customs, finance, law and other related 
standards, norms are still not perfect, agricultural market standardization and organization are low, the trust of e-commerce have an effect on farmers friends.

(5) Agricultural products are particular. Many products have seasonal, uneasy storage, so it is difficult to process in the late of preservation and transportation, it is more difficult to make its logistics link relative to the industrial products, and many people have more difficult for agriculture in developing electronic commerce scruples.

(6) The availability of network resource is bad. Due to scarce online resources, high online fair, high rent charge on private data lines, it is not high in expensive period of e-commerce high operating costs.

(7) Personnel qualities and skills. At present, overall culture quality and application of information technology skills of our country agricultural workers are lower; the development of agricultural electronic commerce is limited.

\section{The Development Model Electronic Commerce of Regional Agriculture}

\section{(1) Establish (G2G) 2B mode}

This model is the innovation mode of the agricultural industry of e-commerce, which is based on $\mathrm{G} 2 \mathrm{G}$ and emphasized on G2B. Cohesion in the two flows forms a new concept of agricultural e-commerce mode. Provincial agricultural electronic commerce center is external agricultural information gateway of unity which agricultural management departments are leading, including agricultural information of the area around the city state. Agriculture information resources of agricultural industry uploading of this area are integrated by the background platform of every city and state agricultural electronic commerce center, be the public platform of the regional agricultural information. The information can be shared and unified integrated between platform, and the agricultural service information which is comprehensive, detailed and accurate can be provided to the agricultural e-commerce center, consumers can search information by the unified platform. These regional platforms of the government have strong operability, enhance participation of the agricultural business enterprise, the agricultural business enterprise of agriculture's cognition and trust are improved.

(2) Establish (B2B) 2C mode

This mode bases on the two operation mode of traditional $\mathrm{B} 2 \mathrm{~B}$ and $\mathrm{C} 2 \mathrm{C}$ e-commerce, the regional agriculture enterprises are combined the front and background closely by through the information integration and consumer. The information of agricultural enterprises can be shared between regional areas, the system to solve the enterprise internal and external $\mathrm{E}$ of disconnection issues is provided capital and information flow mutual coordination and two-way communication, information query across the region becomes more convenient. In this mode, consumer could realized by the unified platform, namely could query information of omni-directional comprehensive agricultural and self-help customized service of agricultural projects.

(3) Establish regional agriculture information database of e-commerce invested based on government 


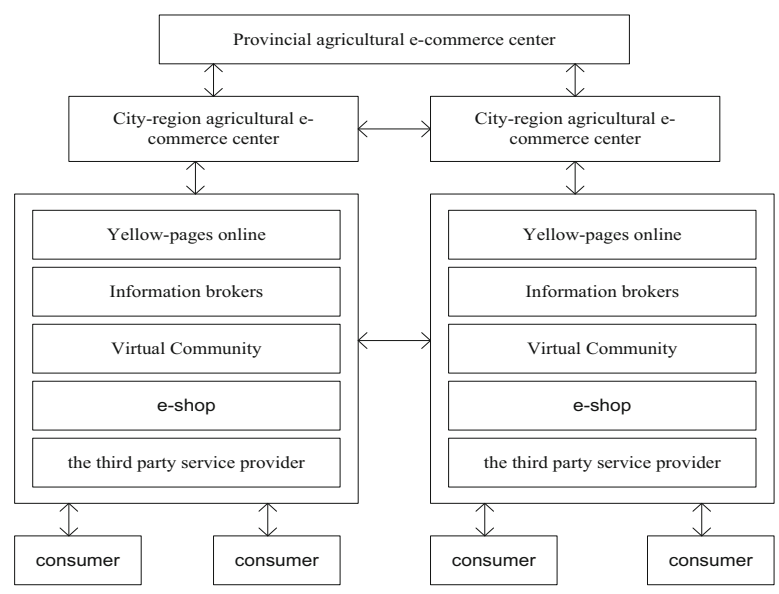

Fig. 1. The development model e-commerce systematic structure of regional agriculture

In the new mode, the government as the macroeconomic manager of agriculture e-commerce has the effect of norm and support. The investment and maintenance costs of agricultural electronic commerce are very large; it is difficult to construct and maintain by the enterprise alone. The region unified enterprise information database is established by the government, many costs of maintenance, personnel training, functional development, etc, are be reduced when the government build their own information platform. Internal management information network of agricultural enterprises are built, information mode transfer to horizontal, agricultural research, forecasting, planning and management of digital, procedure and standardization are realized by inside information management platform. The advantage of regional resource sharing makes database information, accuracy and timeliness strong, the platform has the strict standard model of information, information quality, strict management mechanism and standardization of the management for funds and service platform, there are positive function for after-sales service and guarantee.

(4) Establish many technical integrated application modes

(a) ASP mode: ASP by hiring equipment, software system and communications lines from server vendors, network communication equipment suppliers, operating system developer, database system developers, network security system developers, network management system developers and lines of communication, to construct the application system operation platform[4-5].

(b) Safe management mode: It strengthens the safety of network through the establishment of personnel management, system maintenance and data backup, emergency measures and virus prevention system, etc.

(c) Resource sharing mode: Unstructured information the information may lead to split information, disagree information. Based on the new generation of information cooperation, establish regional platform realizing information resources sharing, and improve the system of regional platform of internal and external information sharing.

(d) Mobile information mode: Developing of $3 \mathrm{G}$ and credit card, maturing of internet technology, and state policies, making the use of mobile business trend more 
widely. Using standardized data as sharing platform, basing on modern information, using modern information technology makes agriculture E-commerce, as the most convenient way to use by public [6-7].

(5) Establish comprehensive service function mode

In the building of new mode, information resources regional sharing is realized, the most personal service to consumers is provided. For instance, professional consulting could be provided by network guide, and according to the needs of different users, comprehensive information and combination are dynamically provided, easy operation interface allows users to design agricultural needs database by them, the information required standard is provided, According to these standards the information for users can be the most qualified provided by the database [8-10]. Various forms of services form as internet, telephone, mobile digital terminals, etc. make users enjoy comprehensive services. These overall images of agriculture can be promoted vividly by the openly agricultural information distribution system.

\section{Study of the Regional Agricultural Electronic Commerce Development Mode}

Through a new development model electronic commerce of regional agriculture base on the government as above, and analyzed such key issues as problems of the security applications, payment mode, sharing mechanisms, and legal protection [11-13], etc. The discussion on the among coordination mechanism of the region, it is significance for regulating the development of agricultural e-commerce and promoting the regional economical development.

(1) Security mechanism

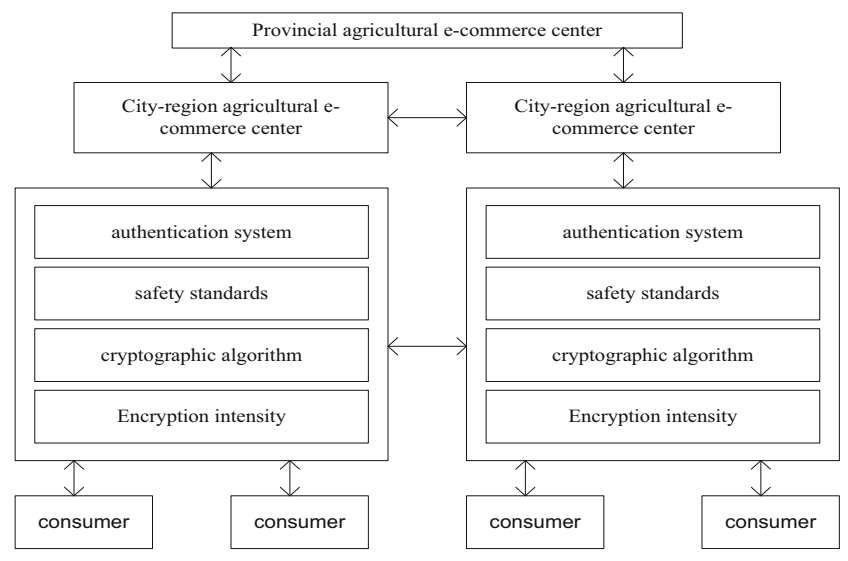

Fig. 2. Security Application mechanism

Agricultural e-commerce security mechanism, such as authentication system, safety standard, encryption algorithm and encryption intensity, they are mainly applied in trading, the share of information, network, etc, G2C G2B G2G in, and B2C and $\mathrm{B} 2 \mathrm{~B}, \mathrm{C} 2 \mathrm{C}$ mode application security mechanisms have been very good. 
(2) Payment mechanism

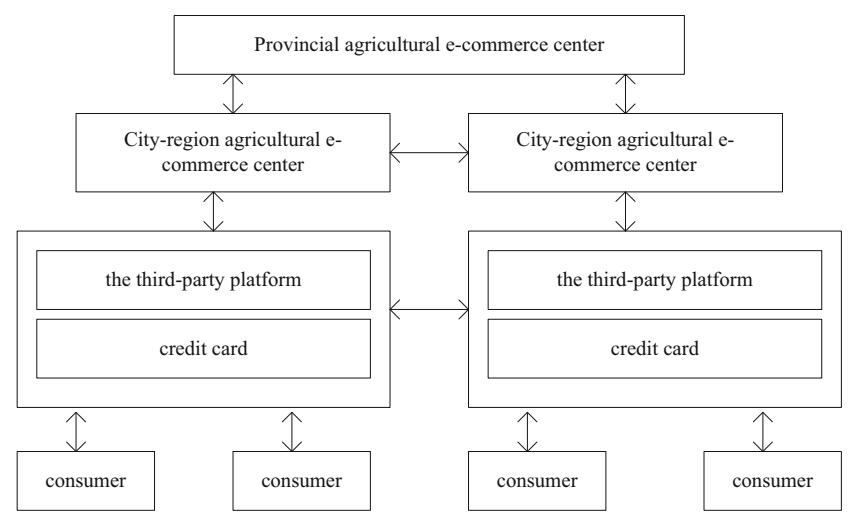

Fig. 3. Payment mechanism

In numerous agreements and method, the credit card is the most convenient and fast, it provides accurate data encryption, electronic signature and identity authentication, it has been mainly agricultural electronic commerce in developed countries. But in China, agricultural electronic commerce is mainly to provide the third's platform for the trade, such as the trades between regional and regional, between customers and consumers, between enterprise and enterprise, between consumers and business, can be accomplished by using the third's platform.

(3) Shared mechanism

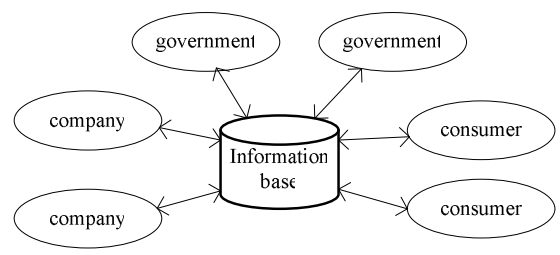

Fig. 4. Shared mechanism

The sharing mechanisms of establishment need of enterprise and consumer, which can analyze, investigate, forecast and plan. The data obtained are datamation, programmed and standardization, then this information are stored to database, some enterprises or governments can share them, but some between the enterprise and government which are limited can not share with resources.

(4) Legal assurance mechanism

Legal guarantee mechanism suitable G2C, G2G, G2B, C2C, B2C and B2B model, at the framework of the legal system, we should pay attention to coordination between the construction of legal system and special form. In the value orientation of the legal system, the related legal should be paid to consumers, especially the individual 
consumer's protection. In the specific contents of the legal system, they need to set up necessary access conditions, the rights between the bank and the customer, Signature and certification, Trading evidence, the responsibility when accidents caused loss, the problem between International law appliance and the jurisdictional.

\section{Conclusion}

A new development model electronic commerce of regional agriculture base on the government of (G2G) 2B is constructed; the environment of e-commerce is regulated. At the same time, the (B2B) $2 \mathrm{C}$ resource sharing public support platform of the participation and cooperation is built, the guide and resource integration of enterprise website, e-commerce site agriculture business is strengthened, the overall level of the agricultural informatization is improved. In this, the regional government of agricultural information database is built, and some related mechanisms of managements or other aspects are also built, standardize trade standards. The integrated applications mode of various techniques are established, it provides the Omni-directional support for the development of agriculture. At last, the integrated service mode is established, humanization, intelligent, personalized service is provided, self-help customized service become the possibility.

\section{References}

[1] Lee, X.: Agricultural E-commerce Spring. Farmers' Daily (September 28, 2006)

[2] Zhao, Y., Lee, L., Lv, J.: Analysis of Agricultural E-commerce Development. Countryside of economy and technology (5), 24-25 (2006)

[3] Zou, J.: The Analysis of Agricultural the Third-Party E-commerce Mode in China. Trade Time (9), 75-79 (2007)

[4] Christiaanse, E., Huigen, J.: Institutional Dimensions in Information Technology Implementation in Complex Network System. European Journal of Information System 6, 77 85 (1997)

[5] Henderson, J., Dooley, F., Akridge, J.: Internet and E-Commerce Adoption by Agricultural Input firms. Review of Agricultural Economics 26(4), 505-520 (2004)

[6] Kuan, K.K.Y., Chau, P.Y.K.: A Perception-Based Model for EDI Adoption in Small Business Using a Technology Organization Environment Framework. Information\& Management 38, 507-521 (2001)

[7] Kraemer, K.L., Dedrick, J.: Strategic Use of Internet and E-commerce: Cisco System. Journal of Strategic Information System 11, 5-29 (2002)

[8] Walsha, S., Linton, J.D.: The measurement of technical competencies. Journal of High Technology Management Research 13, 63-86 (2002)

[9] Christophe, R.D.: Building core competencies in crisis management through organizational learning.Technological Forecasting and Social Change 19(2), 113-127 (1999)

[10] Barney, J.B.: Firm resource and sustained competitive advantage. Journal of Management 17(1), 99-120 (1991) 
[11] DeCarolis, D.M.: Competencies and Imitability in the Pharmaceutical Industry: An Analysis of their Relationship with Firm Performance. Journal of Management 29(1), 27-50 (2003)

[12] Lado, A.A., Wilson, M.C.: Human resource systems and sustained competitive advantage: a competency-based perspective. The Academy of Management Review 19(4), 699-727 (1994)

[13] Johannessen, J.-A., Olsen, B.: Knowledge management and sustainable competitive advantages: The impact of dynamic contextual training. International Journal of Informational Management 23(23), 277-289 (2003) 